\title{
Sosialisasi Peran Badan Narkotika Nasional Kabupaten Karawang Serta Masyarakat Dalam Upaya Pencegahan Penyalahgunaan Narkotika di Masa Pandemi Covid-19
}

\author{
Oci Senjaya*1, Candra Hayatul Iman², Rina Marlina ${ }^{3}$ \\ 1,2,3Fakultas Hukum, Universitas Singaperbangsa Karawang \\ *e-mail: oci.senjaya@fh.unsika.ac.id ${ }^{1}$, candra.hayatul@fh.unsika.ac.id ${ }^{2}$, rinakebidanan@gmail.com ${ }^{3}$
}

\begin{abstract}
The circulation of narcotics has actually increased during the Covid-19 pandemic. One of the countermeasures is through integrated Community Service (PkM) activities with Thematic KKN activities. The purpose of implementing this activity is so that the public is aware of several BNNK programs during the pandemic. The method of implementing PkM is carried out with social media facilities, this is used for data search, socialization, outreach to BNNK partners with village / urban village representatives in Karawang Regency, including making applications, Whatsapp groups, social media other, this activity is hoped to be an effort to prevent drug abuse during the Covid-19 pandemic with Whatsapp groups and the media. other social media to exchange information related to efforts to prevent narcotics abuse during the Covid-19 pandemic.
\end{abstract}

Keywords: Socialization, Role of BNNK, Pandemic COVID-19, Drugs

\begin{abstract}
Abstrak
Peredaran narkotika justru meningkat pada masa pandemi Covid-19. salah satu penanggulangan dilakukan melalui kegiatan Pengabdian kepada Masyarakat (PkM) terintegrasi dengan kegiatan penelitian serta KKN Tematik. Tujuan pelaksanaan kegiatan ini agar masyarakat mengetahui beberapa program BNNK selama pandemi. Metode pelaksanaan PkM dilakukan dengan Sarana media sosial, ini digunakan untuk pencarian data, sosialisasi, penyuluhan kepada mitra BNNK dengan perwakilan desa/kelurahan di Kabupaten Karawang diantaranya pembuatan aplikasi, grup Whatsapp, Instagram, Facebook, Twitter, Youtube. Dari kegiatan PkM ini yang telah dilaksanakan dapat disimpulkan masih ada masyarakat yang tidak banyak mengetahui tentang peran BNNK dimasyarakat selain pemberantasan juga melakukan upaya pencegahan penyalahgunaan narkotika di masyarakat, kegiatan ini diharapakan sebagai upaya pencegahan penyalahgunaan narkoba di masa pandemi covid-19 dengan grup Whatsapp maupun media sosial lainnya untuk saling bertukar informasi terkait upaya pencegahan penyalahgunaan narkotika di masa pandemik covid-19.
\end{abstract}

Kata Kunci: Sosialisasi Peran BNNK, Pandemi COVID-19, NAPZA

\section{PENDAHULUAN}

Ditengah keresahan bangsa ini terhadap wabah yang tengah melanda hampir seluruh dunia yaitu Covid-19, ada juga hal yang sama perlu perhatian lebih pada masa pandemi ini, yaitu peredaran NAPZA yang semakin meningkat di tengah pandemi yang sedang melanda. Pada masa pandemi ini telah banyak aktivitas terhenti seperti pendidikan, ekonomi, keagamaan dan lain sebagainya. Berbanding terbalik dengan peredaran NAPZA, dalam situasi seperti ini peredaran NAPZA malah semakin meningkat karena para pengedar memanfaatkan situasi sulit saat ini (Sasangka, 2003). Contoh nyata yang bisa terlihat oleh semua bangsa Indonesia adalah banyaknya publik figur yang turut terjerumus pada penyalahgunaan NAPZA di masa pandemi Covid-19 ini. Sebelum pandemi ini melanda, dampak yang ditimbulkan akibat pemakaian NAPZA ini sudah sangat berbahaya bagi manusia. Bahaya dan dampak yang akan terasa jika seseorang menyalahgunakan NAPZA bagi hidup dan kesehatannya adalah sebagai berikut, yang pertama adalah dehidrasi, tubuh akan mengalami kekurangan cairan karena keseimbangan elektorit berkurang.

Badan Narkotika Nasional (BNNK) Kabupaten Karawang terus memperketat Pencegahan, Pemberantasan, Penyalahgunaan, dan Peredaran Gelap Narkotika (P4GN) di masa pandemi ini. Pandemi ini tidak menurunkan potensi peredaran narkotika dan obat-obatan terlarang (narkoba) di masyarakat (bnn.go.id, 2019) salah satu faktor terpenting dalam upaya P4GN adalah partisipasi aktif masyarakat untuk turut peduli dalam mengawasi lingkungan di sekitarnya. Hal tersebut 
merupakan kekuatan terbaik untuk mencegah narkotika merusak generasi muda. Masyarakat harus peduli dengan lingkungannya. Kalau menemukan ada peredaran jangan tinggal diam, tapi harus melaporkan dan berkoordinasi agar bisa ditindaklanjuti dengan penegakkan hukum maupun penanganan lainnya (nasional.republika.co.id, 2020).

BNNK Kabupaten Karawang perkuat supply reduction ini dengan pemberdayaan masyarakat dan peningatan layanan rehabilitasi untuk pecandu, atau orang yang sudah terlanjur mengonsumsi narkotika. Sementara itu, Pemerintah Daerah Kabupaten Karawang melalui Badan Kesatuan Bangsa dan Politik (Kesbangpol) juga selalu berkoordinasi dengan kewilayahan, pihak desa-desa,kelurahan, kecamatan,pihak sekolah, dan mitra- mitra lain untuk mendukung P4GN dengan sosialsiasi. Maupun pihak lainnya juga yang membantu memfasilitasi sosialisasi peran BNNK dan masyarakat dalam gerakan anti narkoba di sekolah-sekolah dan lingkungan desa/kelurahan disekitar wilayah Kabupaten Karawang. dengan cara itu bisa membantu masyarakat untuk semakin sadar dalam berperan aktif memberantas narkotika. Sebagai perguruan tinggi yang ada di provinsi Jawa Barat, maka Universitas Singaperbangsa Karawang (UNSIKA) terpanggil untuk berkontribusi dalam pencegahan dan penanganan dampak Covid-19 yang sedang mewabah di masyarakat terhadap kehidupan bidang kesehatan masyarakat peran BNNK serta masyarakat dalam pencegahan penyalahgunaan narkotika pada masa pandemic covid-19. Melalui Lembaga Penelitian dan Pengabdian Kepada Masyarakat (LPPM) yang ada di lingkungan Universitas Singaperbangsa Karawang (UNSIKA) merumuskan kegiatan Pengabdian Kepada Masyarakat (PkM) terintegrasi dengan Kuliah Kerja Nyata Tematik di Masa Pandemi Covid-19 untuk percepatan penanggulangan dalam pemecahan masalah kebencanaan dalam rehabilitasi dan rekonstrukturisasi bencana akibat pandemic Covid-19.

Kegiatan Pengabdian Kepada Masyarakat (PkM) terintegrasi dengan Kuliah Kerja Nyata (KKN) Tematik merupakan kegiatan yang terjadwal secara akademik di Universitas Singaperbangsa Karawang (UNSIKA). Oleh karena itu, percepatan dampak Covid-19 sangat srategis jika dilakukan melalui kegiatan Pengabdian Kepada masyarakat (PkM) terintegrasi dengan kegiatan Kuliah Kerja Nyata (KKN) Tematik. Pengabdian Kepada Masyarakat merupakan wujud dari tri dharma perguruan tinggi serta merupakan salah satu bentuk pengabdian kepada masyarakat yang dilakukan oleh tim dosen lintas fakultas/prodi secara interdisipliner, institusional, dan kemitraan sebagai salah satu wujud dari tridharma perguruan tinggi. Program pengabdian kepada masyarakat dipandang oleh Universitas Singaperbangsa Karawang (UNSIKA) sebagai program yang wajib dilaksanakan, baik oleh dosen maupun oleh mahasiswa, yang diharapkan dapat menghasilkan program pengabdian kepada masyarakat yang bermutu, relevan, dan sinergis dalam meningkatkan pemberdayaan masyarakat Hal tersebut yang melatar belakangi kegiatan Pengabdian Kepada Masyarakat (PkM) "Sosialisasi" terintegrasi dengan kegiatan KKN ini adalah untuk membantu peran BNNK Kabupaten Karawang serta masyarakat kabupaten karawang agar mudah dalam mengakses informasi-informasi dan menemukan pemecahan masalah terkait kendala yang dialami oleh sebagian besar masyarakat yang menyalahgunakan narkotika (pencandu) narkotika maupun zat adiktif lainnya di masa pandemi Covid-19, sejalan dengan judul PkM kami yaitu "Sosialisasi Peran Badan Narkotika Nasional Kabupaten Karawang Serta Masyarakat Dalam Upaya Pencegahan Penyalahgunaan Narkotika Di Masa Pandemi Covid-19".

\section{METODE}

Pengabdian kepada masyarakat (PkM) di masa Pandemi Covid-19 terintegrasi dengan penelitian dilakukan dengan menggunakan pendekatan masalah sebagai berikut :

\section{Pendekatan Individual}

Pendekatan Individual yang dimaksud adalah mahasiswa melaksanakan program Kuliah Kerja Nyata Tematik secara individual di lokasi sekitar tempat tinggal., dan mahasiswa melaksanakan kegiatan dengan menggunakan media sosial atau media yang lain sesuai dengan protokoler penanganan Pandemi. 
2. Pendekatan Kelompok terbatas

Pendekatan kelompok terbatas adalah mahasiswa melaksanakan kegiatan bersama dengan teman yang melakukan KKN yang berada pada 1 Desa/Kelurahan,sekolah-sekolah dengan tetap melakukan komunikasi secara daring. Selain itu pendekatan kelompok terbatas bisa dilakukan dengan teman yang berbeda bidang keahlian sesuai dengan kebutuhan, dengan tetap melakukan komunikasi secara daring.

3. Kaderisasi

Pendekatan kaderisasi adalah pendekatan mahasiswa yang dilakukan secara individu atau kelompok terbatas dengan tujuan membentuk kader atau agen pembaharu untuk menindaklanjuti kegiatan yang sudah dilaksanakan. Pendekatan ini dilakukan dengan tetap membuat kelompok diskusi antara mitra BNNK Kab.Karawang, desa/kelurahan/ sekolahsekolah dengan mahasiswa KKN yang tergabung adalah grup sosialisasi BNNK.

Pelaksanaan PkM ini dilakukan dengan menggunakan dan membuat media sosial. Strategi dengan menggunakan media social ini merupakan strategi pencarian data, sosialisasi, penyuluhan, pembuatan dan penggunaan media sosial di dalam pelaksanaan program PkM yang terintegrasi dengan Kuliah Kerja Nyata. Pembuatan media sosial diantaranya pembuatan aplikasi, grup Whatsapp, Instagram, Facebook, Twitter, Youtube. Penggunaan media di dalam pelaksanaan adalah berbasis media sosial dengan jenis media sesuai dengan kesepakatan, baik yang dilakukan oleh DPL, mahasiswa dan mitra sasaran program.

Metode Pelaksanaannya dilakukan di lingkungan tempat tinggal mahasiswa. Anggota PkM dengan Strategi yang dimaksud adalah lingkungan rumah sekitar mahasiswa anggota PkM tinggal merupakan lokasi kegiatan dan domisili sasaran program. Antara lain Sasaran program tersebut adalah sekolah-sekolah, desa/kelurahan serta masyarakat dari komunitas lainnya yang mengalami dampak akibat Covid-19,yang kuramgnya pemahaman edukasi,informasi seputar bahanya narkotika pada masa pandemi covid-19 di wilayah Kabupaten Karawang yang Dilakukan dengan mengembangkan jejaring dengan Desa/Kelurahan, sekolah-sekolah melalui media sosial.

Strategi yang dimaksud adalah strategi yang dilakukan oleh mahasiswa peserta Kuliah Kerja Nyata dan DPL serta tim PkM melakukan kerja sama dengan Kepala Desa terutama di lingkungan terdekat dengan sasaran program Sekolah-sekolah Dilakukan dengan mengembangkan jejaring dengan media cetak, media online dan media elektronik, Tim PkM beserta mahasiswa peserta Kuliah Kerja Nyata dan DPL menginformasikan ke mitra BNNK kabupaten Karawang dengan media online dan media elektronik. Bagi Tim PkM dengan mahasiswa peserta KKN menyampaikan program pelaksanaan ini dengan metode daring dengan menggunakan media social. Strategi ini digunakan oleh tim PkM dan mahasiswa KKN serta DPL di dalam melakukan pendataan para mitra BNNK Kab.Karawang terdampak Covid-19 menggunakan media sosial. Model Pembimbingan yang dilakukan oleh DPL dengan tim PkM serta mahasiswa dilakukan dengan berbasis media sosial juga dengan mitra terkait. Tatap muka dilaksanakan secara terbatas antara tim PkM,mahasiswa peserta KKN dengan DPL jika diperlukan dengan memperhatikan protokol Kesehatan dalam pencegahan Covid-19.

\section{HASIL DAN PEMBAHASAN}

Kegiatan PkM dengan terintegrasi kegiatan KKN Tematik ini dilakukan pada bulan Oktober dan Nopember 2020 dilaksanakan di BNNK Kabupaten Karawang dan dibeberapa Desa/Kelurahan tempat tinggal tim penelitian dan abdimas, dari Sosialisasi diberbagai mitra baik pelaksanaannya secara during maupun luring kegiatan yang dihimpun berdasarkan Sosialisasi peran badan narkotika nasional Kabupaten Karawang serta masyarakat dalam upaya pencegahan penyalahgunaan narkotika pada kondisi pandemi covid-19. Respon atas pelaksanaan program sosialisasi tersebut sangat baik dan antusias khususnya di kalangan pelajar/remaja di sekolahsekolah yang banyak mendapatkan edukasi pengetahuan terkait bahanya narkotika dimasa pandemi-covid 19 saat ini.peserta sosialisasi selain masyarakat umum serta siswa/siswi sekolah- 
sekolah di Kabupaten Karawang. berikut jadwal pelaksanaan pengabdian kepada masyarakat (PkM) yang telah dilaksanakan :

Tabel 1. Pelaksanaan Pengabdian Kepada Masyarakat (PkM)

\begin{tabular}{|c|c|c|c|}
\hline No & $\begin{array}{c}\text { Tanggal } \\
\text { Pelaksanaan }\end{array}$ & Kegiatan KKN & Tujuan Kegiatan \\
\hline 1. & $\begin{array}{c}\text { Hari Rabu } \\
\text { Tanggal } 14 \\
\text { Oktober } 2020 \text {, } \\
\text { 12:16:07 PM }\end{array}$ & $\begin{array}{l}\text { Pembuatan Video Sosialisasi } \\
\text { BNNK Kab.Karawang }\end{array}$ & $\begin{array}{l}\text { Hari Rabu Tanggal } 14 \text { Oktober 2020, } \\
\text { 12:16:07 PM }\end{array}$ \\
\hline 2. & $\begin{array}{l}\text { Hari Jumat } \\
\text { Tanggal } 16 \\
\text { Oktober } 2020 \text {, } \\
\text { 10.00 PM }\end{array}$ & $\begin{array}{l}\text { Pembuatan Program Abdimas } \\
\text { sistem pendataan infografis } \\
\text { untuk BNNK Karawang }\end{array}$ & $\begin{array}{l}\text { Utuk memberikan informasi data } \\
\text { data terkait kasus penyalahgunaan } \\
\text { narkotika di BNNK Kab.Karawang }\end{array}$ \\
\hline 3. & $\begin{array}{l}\text { Hari Jumat } \\
\text { Tanggal } 30 \\
\text { October 2020, } \\
\text { 01:00:00 PM }\end{array}$ & $\begin{array}{l}\text { Melaksanakan } r \text { Kegiatan } \\
\text { Pelaksanaan Program Abdimas } \\
(\mathrm{PkM}) \text { Sosialisasi } \quad \text { upaya } \\
\text { pencegahan penyalahgunaan } \\
\text { narkotika dimasa pandemi } \\
\text { covid-19. Melalui Webinar } \\
\text { Diskusi Online dengan BNNK } \\
\text { Karawang Via Daring }\end{array}$ & $\begin{array}{l}\text { Memberikan Sosialisasi kepada } \\
\text { masyarakat serta pendampingan } \\
\text { kepada para mitra abdimas BNNK } \\
\text { Kab.Karawang agar dapat } \\
\text { memahami dan memanfaatkan } \\
\text { informasi dari kegiatan Abdimas } \\
\text { melalui Webinar upaya pencegahan } \\
\text { penyalahgunaan narkotika dimasa } \\
\text { pandemi covid-19. via daring. }\end{array}$ \\
\hline 4. & $\begin{array}{l}\text { Hari Rabu } \\
\text { Tanggal 04 } \\
\text { November 2020, } \\
\text { 12:17:58 PM }\end{array}$ & $\begin{array}{l}\text { Sosialisasi dengan Mitra } \\
\text { Abdimas penyerahan banner } \\
\text { dan poster dalam hal sosialisasi } \\
\text { pencegahan penyalahgunaan } \\
\text { narkotika di Desa Plawad dan } \\
\text { Desa Puserjaya Kab. Karawang }\end{array}$ & $\begin{array}{l}\text { Mensosialisasikan kepada mitra } \\
\text { Abdimas BNNK Kab.Karawang upaya } \\
\text { pencegahan penyalahgunaan } \\
\text { narkotika dimasa pandemi covid-19 }\end{array}$ \\
\hline 5. & $\begin{array}{l}\text { Hari Jumat } \\
\text { Tanggal 06 } \\
\text { November 2020, } \\
09.00 .10 \text { PM }\end{array}$ & $\begin{array}{lrr}\text { Sosialisasi } & \text { dengan } & \text { Mitra } \\
\text { Abdimas penyerahan banner } & \\
\text { dan poster dalam hal sosialisasi } \\
\text { pencegahan } & \text { penyalahgunaan } \\
\text { narkotika } & \text { di } & \text { Desa } \\
\text { Palumbonsari } & \text { dan } & \text { Kelurahan } \\
\text { Karawang } & \text { Wetan } & \text { Kab. } \\
\text { Karawang } & & \end{array}$ & $\begin{array}{l}\text { Mensosialisasikan kepada mitra } \\
\text { Abdimas BNNK Kab.Karawang upaya } \\
\text { pencegahan penyalahgunaan } \\
\text { narkotika dimasa pandemi covid-19. }\end{array}$ \\
\hline 6. & & $\begin{array}{l}\text { Sosialisasi ke Sekolah SMA } \\
\text { Negeri } 1 \text { Telukjambe Karawang } \\
\text { dan Sekolah SMA Negeri } 3 \\
\text { Karawang }\end{array}$ & $\begin{array}{l}\text { Sosialisasi Online via zoom live } \\
\text { youtube tentang peran BNNK Kab. } \\
\text { Karawang serta masyarakat dalam } \\
\text { upaya pencegahan penyalahgunaan } \\
\text { narkotika pada kondisi pandemi } \\
\text { covid-19. }\end{array}$ \\
\hline
\end{tabular}




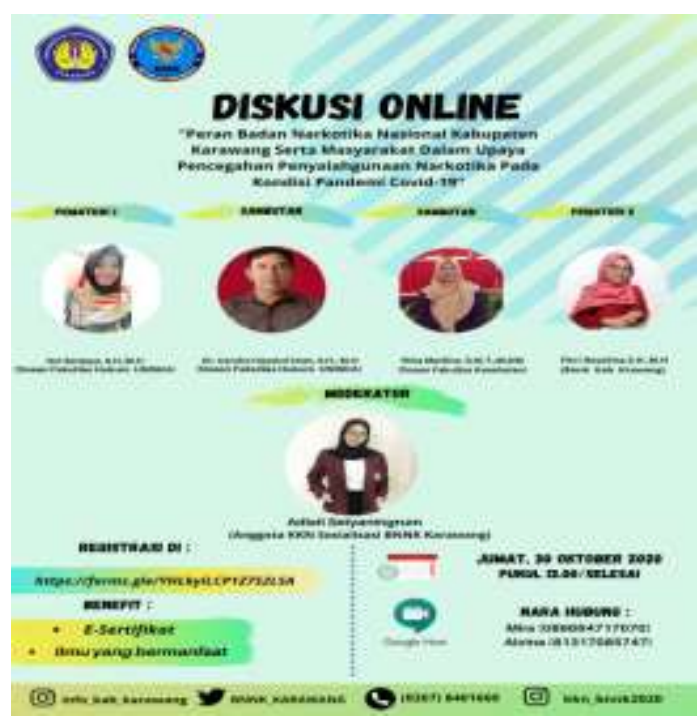

Gambar 1. Sosialisasi dan Diskusi Online "Peran Badan Narkotika Nasional KabupatenKarawang (BNNK) Serta Masyarakat dalam upaya pencegahan penyalahgunaan narkotika pada kondisi pandemic covid-19 via Online.

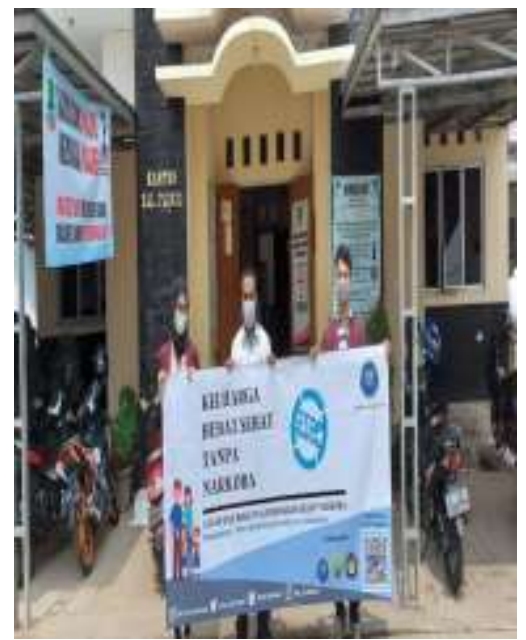

(a)

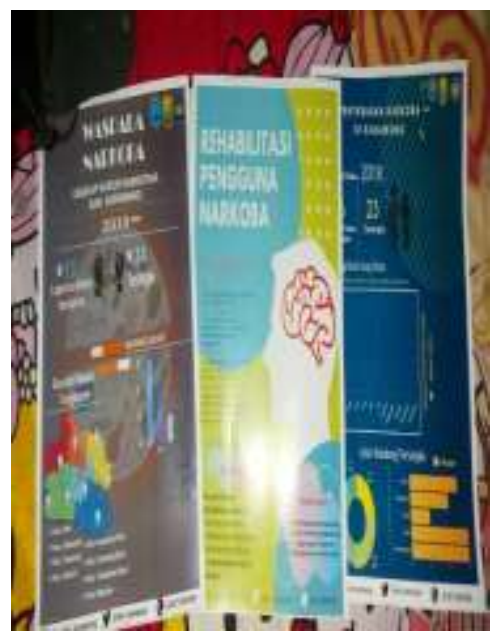

(b)

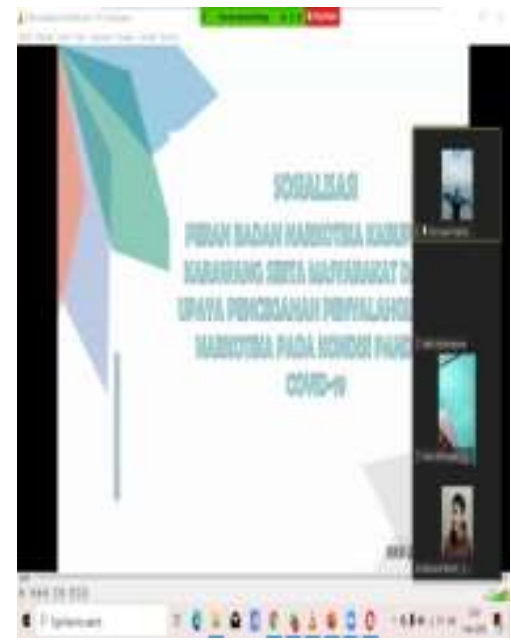

(c)

Gambar 2. (a) Sosialisasi di Desa Puseurjaya dalam rumah (b) Pembuatan Infografis terkait BNNK (c) Sosialisasi During via zoom di sekolah SMA N 1 telukjambe Kab.Karawang

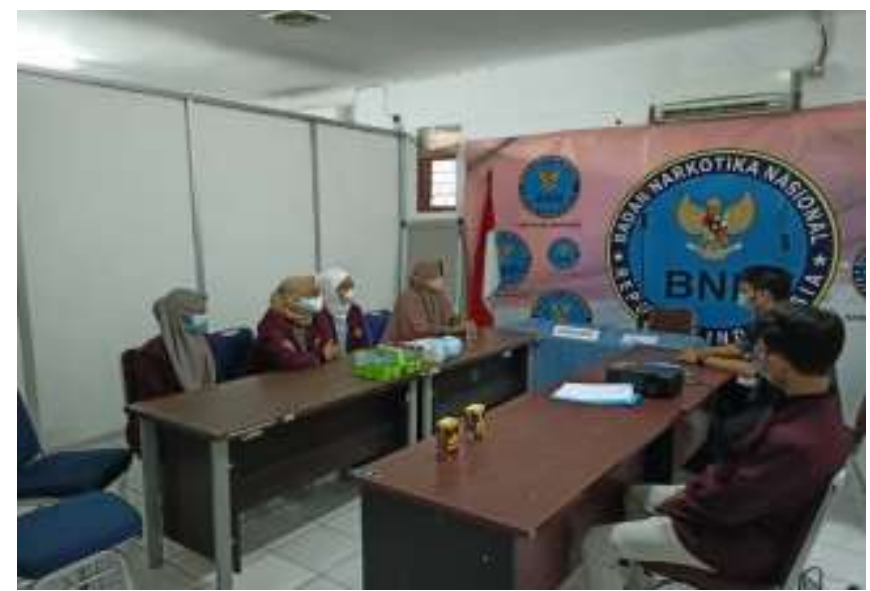

Gambar 3. Hasil Laporan pengabdian kepada masyarakat bersama mitra BNNK Kab.karawang pada awal dan akhir kegiatan pengabdian. 


\section{KESIMPULAN}

1. Faktor pendukung

a. Mitra BNNK Kab.karawang sangat mendukung program sosialisasi pengabdian kepada masyarakat serta memfasilitasi pelaksanaan kegiatan sosialisasi.

b. Mitra Kepala Desa/ Kantor kelurahan sangat membantu kelancaran dan kesuksesan pelaksanaan kegiatan pengabdian kepada masyarakat.

c. Antusiasme peserta dalam mengikuti program pengabdian kepada masyarakat yang dilakukan.

2. Faktor Penghambat

a. Keterbatasan waktu pelaksanaan pengabdian kepada masyarakat.

b. Kondisi Kab.Karawang yang sedang zona merah pandemi covid-19

c. masih ada yang tidak mengetahui program-program BNNK kab.Karawang. Kegiatan Abdimas ini dilakukan dengan tindakan lebih lanjut yaitu pendampingan kepada BNNK Kab.Karawang dengan grup Whatsapp untuk saling bertukar informasi untuk peningkatan upaya pencegahan penyalahgunaan narkotika dimasa pandemi covid-19 sekarang ini.

\section{UCAPAN TERIMA KASIH}

Dengan ini kami tim penelitian dan Pengabdian kepada masyarakat (PkM) Universitas Singaperbangsa Karawang menyampaikan ungkapan penghargaan tinggi dan ucapan terima kasih yang tak terhingga kepada:

1. Prof. Dr. Sri Mulyani, AK., CA. selaku Rektor Universitas Singaperbangsa Karawang

2. Para staff Lembaga Penelitian dan Pengabdian pada Masyarakat (LPPM),

3. Badan Narkotika Nasional Kabupaten Karawang yang telah bersedia menjadi mitra Penelitian dan pengabdian kepada masyarakat (PkM)

4. Semua Aparat Desa yang telah membantu kelancaran pelaksanaan Abdimas (PkM)

5. Para mitra sekolah-sekolah yang bersedia sebagai mitra yang terlibat dalam kelancaran pelaksanaan Abdimas (PkM)

6. Pihak-pihak terkait lainnya atas segala peran aktif, bantuan baik moril maupun material yang memungkinkan kegiatan penelitian dan abdimas berlangsung sukses.

Akhirnya dengan hati tulus dan dengan segala kerendahan hati atas berbagai keterbatasan, kami tim penelitian dan pengabdian kepada masyarakat (PkM) Universitas Sigaperbangsa Karawang menyampaikan ucapan terimakasih semoga bermanfaat bagi lembaga dan masyarakat.

\section{DAFTAR PUSTAKA}

Azizah M. Fitri, Fajaria Nur Candra.Terry,Y.R.Pristya. Pelatihan Upaya Kesehatan Kerja Bagi Masyarakat Cipayung Kota Depok. DINAMISIA: Jurnal Pengabdian Kepada Masyarakat Vol. 4, No. 4 Desember 2020, Hal.605-610DOI: https://doi.org/10.31849/dinamisia.v4i4.4366.

Agus Lanini, Ikhsan Syafiuddin. Peningkatan Kesadaran Hukum Tentang Konservasi Lingkungan BagiMasyarakat Watutela. DINAMISIA: Jurnal Pengabdian Kepada Masyarakat Vol. 4, No. 4 Desember 2020, Hal. 701-707.DOI: https://doi.org/10.31849/dinamisia.v4i4.4114

BNN. (2011). Penyalahgunaan Narkoba. Jurnal Health \& Sport. BNN. (2019). Pengertian Narkoba Dan Bahaya Narkoba Bagi Kesehatan. BNN. (2020a).

BNN Tetap Ungkap Peredaran Narkoba Ditengah Pandemi Covid-19. Bnn.Go.Id. https://bnn.go.id/bnn-tetap-ungkapperedaran-narkoba-ditengah-pandemi covid-19/ BNN. (2020b). Ramadhan: Ancaman Narkoba Di Tengah Pandemi Corona. 
Bnn.Go.Id. https://bnn.go.id/ramadhanancaman-narkoba-tengah-pandemicorona/ Emrald Alamsyah, I. (2019).

BNN: Tingkat Prevalensi Penyalahgunaan Narkoba Meningkat. Republica.Co.Id. https://nasional.republika.co.id/berita/q2twc9349/bnn-tingka prevalensipenyalahgunaannarkoba-meningkat

Hari Sasangka, (2003).Narkotika dan Psikotropika Dalam Hukum Pidana Untuk Mahasiswa dan Praktisi Serta Penyuluh Masalah Narkoba, Mandar Maju, Bandung, hlm. 35

https://bnn.go.id/bnn-menyapa-warga-sosialisasikan-bahaya-narkoba-covid/ 29

https://sumeks.co/bnn-tak-hanya-sosialisasi-bahaya-narkoba-warga-juga-diminta-cegah-covid$19 /$

https://maritim.go.id/konten/unggahan/2020/04/Majalah-ke-7-Jan-Maret-2020-UPConvert.pdf

Kholik, S., Mariana, E. R., \& Zainab. (2014). Faktor-Faktor yang Mempengaruhi Penyalahgunaan Narkoba Pada Klien Rehabilitasi Narkoba di Poli Napza RSJ Sambang Lihum. Kesehatan. https://doi.org/https://doi.org/10.31964/js

Mahardika,(2011).Undang-undang Narkotika Nomor $35 \quad$ Tahun 2009 Tentang Narkotika.Yogyakarta.

Taufik Makarao,Suhasril, Moh Zakky A,S, (2003) Tindak Pidana Narkotika,Ghalia Indonesia, Jakarta

Tim COVID-19 IDAI. (2020). Protokol Tatalaksana Covid-19. In 1. https://klikpdpi.com/bukupdpi/wpcontent/uploads/2020/04/ProtokolTatalaksanaCOVID-19-5OP-FINALok.pdf

Yuliana. (2020). Corona virus diseases (Covid -19); Sebuah tinjauan literatur. Wellness and Healthy Magazine. https://wellness.journalpress.id/wellness/ article/view/21026/pdf 